15 Griff S, Schönfeld N, Ammenwerth W et al. Diagnostic yield of transbronchial cryobiopsy in non-neoplastic lung disease: a retrospective case series. BMC Pulm Med 2014;14:171.

16 Fruchter O, Fridel L, Rosengarten D et al. Transbronchial cryobiopsy in lung transplantation patients: first report. Respirology 2013;18:669-73.

17 Kropski JA, Pritchett JM, Mason WR et al. Bronchoscopic cryobiopsy for the diagnosis of diffuse parenchymal lung disease. PLoS One 2013;8:e78674.

18 Pajares V, Torrego A, Puzo C et al. [Transbronchial lung biopsy using cryoprobes]. Arch Bronconeumol 2010;46:111-5.

19 Jabbardarjani H, Kiani A, Karimi M, Fakhri M. Cryobiopsy shows better safety profile and diagnostic yield as compared to conventional forceps for interstitial lung disease. Eur Respir $J$ 2014;42(Suppl 57):P2301.

20 Hagmeyer L, Theegarten D, Wohlschläger J et al. Transbronchial cryobiopsy and open lung biopsy in interstitial lung disease: Comparison of two diagnostic tools. Eur Respir J 2014;42(Suppl 57):P2303.

21 Noble PW, Albera C, Bradford WZ et al. Pirfenidone in patients with idiopathic pulmonary fibrosis (CAPACITY): two randomised trials. Lancet 2011;377:1760-9.

22 Morris D, Zamvar V. The efficacy of video-assisted thoracoscopic surgery lung biopsies in patients with interstitial lung disease: a retrospective study of 66 patients. J Cardiothorac Surg 2014;9:45.

23 Kaarteenaho R. The current position of surgical lung biopsy in the diagnosis of idiopathic pulmonary fibrosis. Respir Res 2013;14:43.
24 Maguire MF, Ravenscroft A, Beggs D, Duffy JP. A questionnaire study investigating the prevalence of the neuropathic component of chronic pain after thoracic surgery. Eur J Cardiothorac Surg 2006;29:800-5.

25 Flaherty KR, Andrei A-C, King TE et al. Idiopathic interstitial pneumonia: do community and academic physicians agree on diagnosis? Am J Respir Crit Care Med 2007;175:1054-60.

26 Lynch DA, Godwin JD, Safrin S et al. High-resolution computed tomography in idiopathic pulmonary fibrosis: diagnosis and prognosis. Am J Respir Crit Care Med 2005;172:488-93.

27 Jenkins RG, Simpson JK, Saini G et al. Longitudinal change in collagen degradation biomarkers in idiopathic pulmonary fibrosis: an analysis from the prospective, multicentre PROFILE study. Lancet Respir Med 2015;3:462-72.

28 Win T, Thomas BA, Lambrou T et al. Areas of normal pulmonary parenchyma on HRCT exhibit increased FDG PET signal in IPF patients. Eur J Nucl Med Mol Imaging 2014;41:337-42.

Address for correspondence: Dr J C Porter, Leukocyte Trafficking Laboratory, Centre for Inflammation and Tissue Repair, University College London, 5 University Street, London WC1E 6JF, UK.

Email: Joanna.porter@ucl.ac.uk

\title{
Corrigendum: Headache in an HIV positive patient: diagnostic challenges and approach to treatment
}

\author{
Authors: Andrew Creamer, ${ }^{\mathrm{A}}$ Stefanos Ioannidis, ${ }^{\mathrm{B}}$ Thomas Wilhelm, ${ }^{\mathrm{C}}$ Tabitha Mahungu $^{\mathrm{D}}$ and Marc Lipman ${ }^{\mathrm{E}}$
}

Clinical Medicine 2016;16:548-50

Tabitha Mahungu's name was published with the incorrect spelling. The correct spelling is printed above.

\footnotetext{
Authors: ${ }^{\text {A }}$ core medical trainee, Royal Free London NHS Foundation Trust, London, UK; ${ }^{\text {B }}$ foundation doctor, Royal Free London NHS Foundation Trust, London, UK; C Consultant neuroradiologist, Royal Free London NHS Foundation Trust, London, UK; ${ }^{\mathrm{D}}$ consultant virologist and HIV physician, Royal Free London NHS Foundation

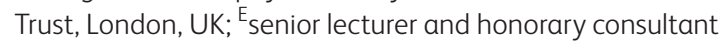
physician in respiratory and HIV medicine, Royal Free London NHS Foundation Trust, London, UK
} 